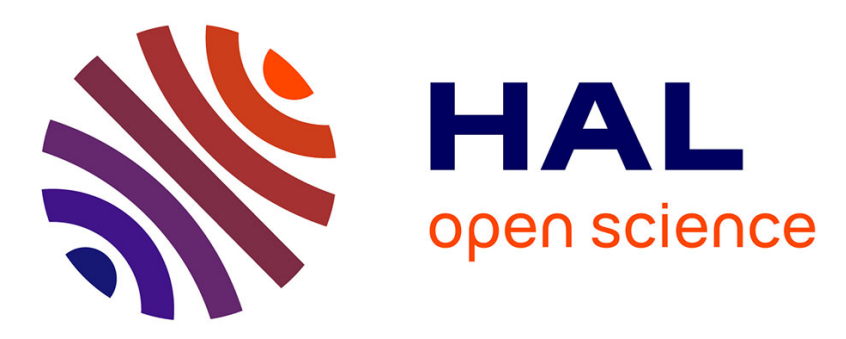

\title{
Inclusion of territorial resources in the product development process
}

\author{
Romain Allais, Tatiana Reyes, Lionel Roucoules
}

\section{To cite this version:}

Romain Allais, Tatiana Reyes, Lionel Roucoules. Inclusion of territorial resources in the product development process. Journal of Cleaner Production, 2015, 94, pp.187-197. hal-01178698

\section{HAL Id: hal-01178698 \\ https://hal.science/hal-01178698}

Submitted on 26 Aug 2015

HAL is a multi-disciplinary open access archive for the deposit and dissemination of scientific research documents, whether they are published or not. The documents may come from teaching and research institutions in France or abroad, or from public or private research centers.
L'archive ouverte pluridisciplinaire HAL, est destinée au dépôt et à la diffusion de documents scientifiques de niveau recherche, publiés ou non, émanant des établissements d'enseignement et de recherche français ou étrangers, des laboratoires publics ou privés. 


\title{
Inclusion of territorial resources in the product development process
}

\author{
Romain Allais ${ }^{\text {a, b, * , Tatiana Reyes }}{ }^{\text {a }}$, Lionel Roucoules ${ }^{b}$ \\ a ICD, Hetic, Creidd, Université de Technologie de Troyes, UMR 6281, CNRS, Troyes, France \\ ${ }^{\mathrm{b}}$ Arts et Metiers ParisTech, CNRS, LSIS, 2 cours des Arts et Metiers, 13617 Aix en Provence, France
}

Keywords:

Sustainable business model

Territorial resources

Sustainable strategy

Eco-design

\begin{abstract}
A B S T R A C T
Facing globalization, territorial competitiveness is considered by (French) public policy makers as promising both economic and social value creation locally. Companies consider territorial specificities when selecting a location (e.g. low production costs, highly qualified labor pool) in a utilitarian perspective. This research proposes encouraging companies to consider territory as a value creation network where exploitable resources flow. The proposal presented in this paper is to integrate these latent territorial resources into the product development process to create value for both the company and its territory in a sustainable perspective. The literature review highlights that current eco design practices have great impact on territories, but that this dimension is not considered in terms of resources. Moreover, current assessment practices are not adapted to overall performance evaluation and need revision to meet the system innovation goal. After clarifying the concept of territory, two industrial cases are provided to analyze how territorial resources were included in the design process and how it improved the overall performance of the company-territory system. From the success factors emerging from literature and cases, a method to release the potential of territorial resources is presented. A revised strategic process dedicated to senior management is proposed as the enabler of system innovation with the intention of improving the design of sustainable products. This paper concludes with the necessary cultural evolution that every stakeholder in the value network must undergo to promote territorial values in a sustainable perspective. This study contributes to the emerging discipline of design for local value creation.
\end{abstract}

\section{General introduction}

From an operational perspective, industrial performance is currently measured by the cost-quality-time triptych. For almost 30 years, the efficiency of manufacturing systems has been optimized by adopting many techniques such as SMED, Kanban, Keisen, 5 S... In the nineties, all those techniques were re-named as "lean"-type techniques (for example lean manufacturing, aimed at eliminating losses and wastes in the manufacturing process resulting from inefficient use of human and material resources and poor time management) (Hines et al., 2004). Approaches of this kind have enabled manufacturers to differentiate themselves from their competitors by optimizing quality and time elements (just-in-time, total quality, etc.), leaving cost as the only measure of added value of the offered products or services. The dominance of cost as a factor in decision making and the globalization of markets has

\footnotetext{
* Corresponding author. ICD, Hetic, Creidd, Université de Technologie de Troyes, UMR 6281, CNRS, Troyes, France.

E-mail address: romain.allais@utt.fr (R. Allais).
}

impelled businesses to relocate production to low-cost countries, sometimes to the detriment of manufacturing quality and time (Habib, 2012). Low-cost countries have, however, responded to the challenge and are now able to offer products in line with the market's expectations. Despite this cost-oriented decision, the current European crisis shows that European manufacturers have lost the cost-quality-time battle. Indeed, collateral damage has led to the loss of many other industrial assets which are hard to recover (e.g. know-how or industrial infrastructure). Considering the failure of the low-cost positioning strategy, it is necessary for industrial companies and politician to find new strategies to preserve local and competitive industry (Brissaud et al., 2013).

At a political level, the main challenge is to prevent the company relocating and, in doing so destroying local employment and associated economic activities. Current policies tend to increase territorial competitiveness thanks to, for example, the creation of clusters or industrial ecology strategies. A cluster is a "geographic concentration of interconnected companies, specialized suppliers, service providers, firms in related industries, and associated institutions (e.g. universities, standards agencies, trade associations) in a particular field that compete but also cooperate" (Porter, 2000). 
Cluster policy can increase the competitiveness of SME (Karaev et al., 2007) but may be questioned for the territorial competitiveness (Delaplace, 2011). Nevertheless, this policy enables knowledge and skill exchanges between actors in a local network perspective. Industrial Ecology (IE) or Industrial and Territorial Ecology (ITE) are regional planning strategies that propose a systematic search for physical or organizational symbiosis at a local scale (e.g. port or industrial area) implementing both physical accounting and social research methods (Schiller et al., 2014). IE and ITE provide innovative solutions to help managers reduce costs and add value to products (Esty, \& Porter, 1998) while coupling territorial economic development and environmental constraints (Buclet, 2011b). Both these strategies aim at facilitating exchanges of tangible or intangible resources (e.g. knowledge or materials) between nodes (actors) of a local network in order to create value for both the companies and the territory. The first challenge of this research is to systematize, for the company, the activation of latent tangible and intangible resources from the territory.

The main challenge for a company's survival is to differentiate itself by demonstrating an alternative set of values to low cost. Economic models have evolved from the linear value creation chain (supplier-business-client) to network models, also referred to as "value constellation" models (Normann, \& Ramirez, 1994). So the value creation system of a company is no longer based on the Porter's model (i.e. strategic positioning in the value chain), but in the restructuration of relationship between stakeholders (Allee, 2000; Normann, \& Ramirez, 1994). Evolution of economic models increases the complexity of company's value creation network knowledge and its performance management. Organizational innovation has come to be a key factor for a company and its stakeholders in a changing, competitive and constrained environment, but its management remains a great challenge.

Companies also differentiate themselves by the valorization of key intangible assets (e.g. brand capital for Luis Vuitton) that create proximity with customers (e.g. Quiksilver and the surfing culture): "today, a firm's intangible assets are often the key element in its competitiveness" (Eustace et al., 2009). Furthermore, sustainability is now considered as a differentiator (Barnett et al., 2014) and environmental and societal performance appear as drivers for current and future business performance (Baden et al., 2009) thus it is necessary to integrate sustainability issues directly at the strategic level (Hallstedt et al., 2013). Pressure from civil society (regulations and consumers) is opening up new markets for products that satisfy other demands (e.g. environmental quality, respect for labor rights). Consequently, design process warrants special attention since it is the determinant of $80 \%$ of a product's environmental impact (De Winter, \& Kals, 1994). Moreover, decisions during the early design stage profoundly determine the product's socio-ecological impacts, positive and negative, throughout its life cycle (Tan, \& McAloone, 2006) and affect all those that follow (Suh, 1990). These "sustainability" values embedded in the product are mainly intangible (e.g. biodiversity protection, fair trade) and create extra value for the customers (e.g. esteem value, membership value). The second challenge for this research is to enable designers to include sustainable values in their daily activities.

The main hypothesis of this paper is that incorporating territorial resources into design process has the potential to increase the environmental, social and economic performance of the company and has positive externalities for its territory.

This research is dedicated to industrial companies and its perimeter is the company within its territory. The proposal is intended to be a bottom-up approach (from company to territory) for territorial resources integration into product development process. Although inspired by industrial symbiosis mechanisms at a territorial scale, our research is dedicated to sustainable design.
Even if designers are the integrators of these territorial alternative resources, they need to be supported by the whole internal value creation network of the company.

\section{Research method}

This research concerns concurrent engineering (i.e. design method that is associated with management processes) (Tomiyama et al., 2009) and uses concepts and tools from strategy, management and accountability on one hand and theories and practices from geographical sciences and land management and planning on the other hand. Even if multi-disciplinary, this research methodology is based on the design research methodology (DRM) proposed by (Blessing, \& Chakrabarti, 2009). This paper presents a literature-based research clarification (RC); a comprehensive descriptive study (DS1) based on industrial cases and, finally, the proposition is contained in the comprehensive prescriptive study (PS). The necessary evaluation of the proposition (comprehensive descriptive study 2) is not included in this communication.

RC: a literature review aims at clarifying and positioning this research. After positioning this research in the field of sustainability, an exploration of eco design, sustainable design, sustainable business models and relative performance tools is performed. Thus, current sustainability practices and their limits at product and company scale are clarified. Secondly, the polysemous concept of territory is clarified first from the perspective of administration then industry. DS1: two industrial cases are presented to understand the influence of the inclusion of territorial resources into design process. These cases are modeled then evaluated thanks to a conceptual framework presented in the industrial case method. Starting from two particular cases, generalized key factors for territorial resource integration emerge. PS: finally, the proposal for territorial resources integration into design process is presented and discussed. This article focuses on the architecture and the coordination between the modules of the method. Further communications will detail the construction of each module (Allais et al., 2015).

\section{Literature review}

Concepts presented below are built on the mainstream comprehension of sustainability (Brundtland, 1987). This definition does not question the capitalist market economy and the associated concept of growth which are responsible for most of the environmental problems (Buclet, 2011a). This research adopts the ambition to sustain the ecosphere (i.e. the planet) (Holmberg, Robèrt, 2000). This is in contradiction with the usual utilitarian approaches of preserving a resource, a product, a company or an organization (Hallstedt et al., 2013). This research is based on the assumption that industrial companies and ecosphere sustainability are compatible if sustainability and competitiveness principles are adopted (Allais et al., 2015).

An anthropocentric definition of sustainability was adopted that focuses on the social sphere and uses the economy as a means (not as a goal) while considering constraints from the environmental sphere. The political sphere is the only legitimate arena to define development guidelines and must find a prominent place and take precedence over economic actors. The territorial dimension should also be taken into account in adapting to local policy constraints to the development of appropriate solutions (Figuière and Rocca, 2008).

\subsection{From eco design to sustainable business models}

This first section of the literature review provides an overview of current eco design practices, performance evaluation and 
sustainable business model regarding the adopted definition of sustainability. A particular focus is put on industrial ecology, a sustainable business model and land management and planning strategy that considers the territory.

\subsubsection{Horizontal and vertical integration}

Eco-design (ED) is defined as the integration of environmental constraints in the product development process (PDP) (ISO 14062, 2002). Its aim is to minimize the environmental impact of a product during its entire lifecycle. Eco-design targets the eco-efficiency of a product (i.e. ecological and economic efficiency). Besides environmental aspects, sustainable design or design for sustainability (DfS) integrates all the dimensions of sustainability in the design process and interrogates the product itself, asking fundamental questions about current consumption paradigms (Spangenberg et al., 2010). However, as many ED tools also incorporate social or societal dimensions and question the dominant paradigm, the distinction between these two terminologies appears unnecessary. Consequently, ED is used here as the integration of sustainability constraints into the development process of product design.

ED methods/tools may be used only by to designers (e.g. environmental checklist...) or a larger set of stakeholders. As examples, design for recoverability (DfR) integrates end-of-life actors (Mathieux et al., 2008; Pialot, \& Millet, 2014), design for sustainable behavior (DfSB) integrates consumers (Lockton et al., 2008; Domingo et al., 2013). Consequently, there is a need for active collaboration between the actors of the value creation system. Collaboration along the value chain (e.g. suppliers-companycustomers-recyclers) (Personnier et al., 2013; Michelin et al., 2014) and collaboration between a company's internal actors on the ED process (Rio et al., 2013) have to be supported by adapted management methods (Zhang, \& Zwolinski, 2012; Pigosso et al., 2013). It can be noticed that both horizontal integration (value chain) and vertical integration (management) are improved by current method and tools.

ED changes the physiognomy of an industrial ecosystem (nature and size of material flows) and also has consequences on its territory (Allais et al., 2013). However, stakeholders involved in the collaboration are "limited" to the value constellation of a company. There is an opportunity to integrate territorial stakeholders as resources that may contribute to value co-creation.

Environmental integration in design has been categorized regarding its innovation potential and the system level concerned: from local improvement at the product level to Eco innovative design at the industrial ecosystem level for (Millet et al., 2003) or system innovation at global scale for (Brezet, 1997). This research aims at supporting system innovation (i.e. sustainable society, cultural change, system performance improvement) at a territorial scale.

\subsubsection{Performance evaluation}

On the one hand, eco design practices are evaluated by assessment tools: Life Cycle Assessment, Life Cycle Cost, etc. that provide information about the environmental performance or the eco efficiency of the product. It is an element of the evaluation of the natural capital (e.g. resource use, emissions...). In spite of several limitations (Laratte et al., 2014), these expert tools enable local decisions regarding environmental performance (e.g. choice of material) and may be part of higher level decisions (Chau, 2007; Zhao et al., 2006) (e.g. shift from pure trade to PSS). However, ED implementation influences other assets of a company: knowledge capital (e.g. innovation), brand (e.g. reputation) or partner capital (e.g. proximity with recycler) that are not valued during the eco design program (Zhang et al., 2013). Consequently, performance evaluation of ED implementation is incomplete. Moreover, product-related decision tools are disconnected from strategic scorecard and operational performance indicators (Zhang et al., 2013). Consequently, even if senior managers understand the potential strategic benefits of ED, its valorization is carried out in an accounting logic (a posteriori) to support institutional communication.

On the other hand, it is mandatory for a growing number of companies to produce an expended balance sheet annually (e.g. sustainability report). These reports contain qualitative and quantitative evaluations of the tangible and intangible assets of a company and its activities. In fact, for long time intangibles have been considered as key drivers for value creation (Edvinsson, 1997) and numerous taxonomies have been proposed from different perspectives (i.e. accountability, management, reporting...) (OECD, 2006). Some integrates the Corporate Social Responsibility (CSR) dimension: the triple bottom line accountability (i.e. profit, people, and planet) (Elkington, 1997) or Porritt's five capitals (i.e. natural, social, manufactured, human and financial) (Porritt, 2007). These tools enable overall performance assessment that has been defined by (Baret, \& Petit, 2010) as the combined sum of economic, social and environmental performance and has the appearance of a measure of the achievement of sustainable development. None of these integrates explicitly the territorial dimension of sustainability.

\subsubsection{Sustainable business models}

Frameworks like Blue ocean strategy ${ }^{1}$ or business model generation $^{2}$ assist senior management in creating new business models and related strategies by challenging their value creation model. The aim of these tools is to sustain a company's business thanks to innovation in the value proposition and the means of delivery to customers. Even if interesting, this does not fully meet the research ambition (i.e. sustaining a company within the ecosphere). However, a business model based on value creation is capable of accommodating the notions of CSR, sustainability and stakeholder involvement at different levels within the business (i.e. strategic and managerial) (Wheeler et al., 2003). Therefore, strategic thinking about value propositions and business models is a great opportunity to integrate sustainability into a company's activity.

(Bocken et al., 2013) propose a review and categorization of Sustainable Business Models (SBM) defined as "Innovations that create significant positive and/or significantly reduce negative impacts for the environment and/or society, through changes in the way the organization and its value-network create, deliver value and capture value or change their value propositions". Among the described SBM industrial ecology integrates the five dimensions of sustainability and thus appears promising to meet this research objective.

\subsubsection{Industrial ecology}

Industrial Ecology (IE) can be defined as seeking synergies between stakeholders to reduce the environmental impacts of human activities on ecosystems (Buclet, 2011b). This dematerialization strategy supports a shift from a linear economy, where natural resources are considered inexhaustible, to a circular economy mainly intangible. In this ideal model, all material flows would be closed. The Lafarge case study presented below is a significant example of the application of IE strategy by a worldwide production company. IE is implemented primarily as an industrial optimization tool. Industrial and Territorial Ecology (ITE) is a strategy of land

\footnotetext{
1 http://www.blueoceanstrategy.com/.

2 http://www.businessmodelgeneration.com/.
} 
management and planning to create economic, societal, social and environmental shared value for the stakeholders of a territory. ITE is a systemic approach that repositions mankind as an element of the biosphere and proposes making human actions compatible with biosphere capacities in a resource scarcity perspective (Buclet, 2011b). The underlying paradigm is that a society has to balance its needs regarding the availability of local resources.

The main obstacle to the implementation of synergies is the poor coordination between actors (i.e. lack of dialog, common interests or trust between companies, local authorities or academics) (Buclet, 2011b). Often, a mediator is needed to smooth difficulties of coordination between senior managers of different organizations. Finally, IE and ITE provide innovative solutions to help managers reduce costs and add value to products (Esty, \& Porter, 1998) while coupling territorial economic development and environmental constraints (Buclet, 2011b). This research proposes systematizing the inclusion of territorial resources in strategic analysis to support the cultural change needed to deploy these SBM.

\subsection{Territories}

As previously seen, territory is a promising perimeter to capture specific intangible values but the concept is used in numerous scientific fields and has multiple definitions. It has to be noted that there is a paradox between the globalization of companies' value networks with the illusion of mastery of space-time (Buclet, 2011a) and its physical reality in a geographical area. Therefore, this review focuses on two definitions both from an industrial perspective (object of the study) and geographical science. Then, a conceptual framework of company's territory is proposed.

\subsubsection{A definition from geographical science}

A territory is not only determined by a geographical area but it is an evolving and complex combination of a set of actors and the geographical space that these actors use, landscape and manage (Moine, 2006). This research uses 4 clusters to describe a territory: natural ecosystems, anthropic ecosystems, industrial ecosystems and social spaces adapted from (Moine, 2006). Each of these ecosystems provides specific tangible and intangible resources. The natural ecosystem provides tangible resources (natural resources) such as gas, wood, water... and intangible such as natural amenities. The anthropic ecosystem is constituted of the whole anthropic objects such as communication networks, cities. It provides tangible resources such as city garbage or facilities and intangibles such as transport services or human resources. The industrial ecosystem is voluntary disconnect from the previous one, although it is an anthropic construction. It provides tangible resources such as second hand materials and intangibles such as expertise. Finally, the social space is the set of social interactions: networks of relationships, organizations. "Systems of representation" are also included in this cluster. They are defined as "the set of individual, societal and ideological filters (values) that shapes the understanding an actor has of his territory" (Callon, Latour cited in Moine, 2006). Social space mainly provides intangible resources such as a common culture, local history or identity.

These clusters are understood as interconnected value creation networks where tangible and intangible resources flow from one reservoir to another. The territory supports many interconnected value chains in a complex network which is combined in a "basket of goods" (Pecqueur, 2001). Each territory has a specific identity due to its intrinsic characteristics (e.g. common culture, history, landscapes...). It may be captured in value propositions of companies to create value for customers. For example, Appellation d'Origine Contrôllée (French label for controlled designation of origin) guarantee the geographical origin of a product, or Entreprise du patrimoine vivant (French label for living heritage company) guarantee a specific traditional knowledge. These clusters enable the description of a territory but we will see that territorial boundaries depend on the stakeholders and the problem to be solved.

\subsubsection{An administrative definition}

The administrative territory is the geographical area managed by political entity (e.g. country, department, regions, city, etc.). Recent French public policies aimed at decentralizing the economy by promoting the attractiveness and empowerment of territories. For the French Economic Analysis Council: "the territory is at the heart of strategies to enhance competitiveness and economic attractiveness" and "can strengthen social cohesion" (Godet et al., 2010). Administrative territories are compatible with the sustainability definition used in this research (i.e. adaptation of public policies to local specificities) but their boundaries are static Consequently, administrative territories lack the necessary flexibility regarding the nature of a problem and the stakeholders involved. Nevertheless, this lack of flexibility is partly mitigated by coordination between territories (i.e. water preservation strategy needs cooperation between the administrative territories of the catchment area) but it reduces the reactivity and makes a proactive approach difficult.

\subsubsection{A definition from industry}

Anytime, companies selected their location regarding the local specificities without a sustainability perspective. Consequently, if the main factor is the reduction of costs, this leads to the negative aspects of globalization with incentive for forced work or environmental disasters. To respond to these crimes, numerous regulations and norms exist including the ISO26000 for Corporate Social Responsibility (CSR). (ISO26000, 2010) defines the sphere of influence of an organization as an "area across which an organization has the ability to affect the decisions or activities of individuals or organizations. Area can be understood in a geographic sense, as well as in a functional sense". It appears to define the boundary of company's sustainability but in the current globalized economy, distance does not exist anymore. Consequently, company's influence sphere is global and rarely localized in a unique geographical area. Currently, the lifecycle of a product is divided between many different actors of the value constellation and has an impact in different parts of the world (Knudsen, 2010).

This research adopts the concept of plurilocal actor (i.e. a company that has its activities on multiple territories) (Buclet, 2011c) and proposes considering the administrative territory and local value creation systems in every location of the sphere of influence of the company. In the same way as accountability scorecards, this proposition needs to be improved by collaboration with experts.

\subsection{Findings from the literature review}

Eco design tools and methods change the objectives locally (at the project level) and enable the integration of sustainable values in the product development process at different system levels. As it modifies the physiognomy of territorial ecosystems (Allais et al., 2013), ED has great influence both on the company and its value creation network (industrial ecosystem). Moreover, ED implementation has consequences on multiple territories where the lifecycle of a product impacts. However, ED does not support territorial resolution (i.e. ED is non-spatialized). As seen previously, territorial specificities are taken into account when choosing implantation site but this consideration is punctual in the company's lifetime. Finally, territorial resources are under-exploited by companies that may find a competitive advantage in exploiting local 
tangible and intangible resources in a sustainable perspective (e.g. secure sourcing, cluster of excellence).

Environmental and social issues must be linked to business decisions and integrated into the global strategy of a company. Sustainable business models such as industrial ecology seem promising solutions but remain difficult to implement due to organizational and managerial challenges. It appears to be necessary to enhance overall strategic thinking: tangible and intangible assets that enable the creation of values (e.g. brand, natural or human capital) are strategic resources that must be managed (i.e. protected or developed). (Lorino, \& Tarondeau, 2006) distinguishes internal and external strategic analysis: external analysis considers the structural factors (market, competition ...) and internal analysis concerns the firm's own resources. This study adopted the resource-based view for competitive advantage (Wernerfelt, 1984; Peteraf, 1993), that is: competitive advantage comes from internal resources and not from external factors. Tangible and intangible resources from the whole value-creating network (i.e. value constellation) are considered as internal resources.

The value constellation is considered here as the nexus of the formal and informal processes that transform tangible and intangible resources within the business (e.g. the product development process, human resources process, strategic process). Added value delivered to customers is created by the network that supports the design activity (e.g. local sourcing, fair trade, eco-efficiency, identity-related aspects of the product). Adapted analytical tools are needed to understand the value-creation system. First, it is necessary to understand how the value is created and then find appropriate tools for system management. Even if expert assessment models and tools exist, they are only assessing local performance and are not connected to the overall performance of the system. There is a need to hybridize current design assessment tools and accountability scorecards to provide a system and integrated scorecard for sustainable business management from strategy to operation.

Companies and public policies may find a common interest in the long term development of their territory. The empowerment of the territories may have positive externalities such as local employment and may be a lever for globalization shortcomings such as relocation of activities: rebalancing competition with countries having lower levels of labor rights or environment regulation and therefore lower costs. This research aims at assisting industrial companies to both explore the use of latent resources from their territory and to assume their responsibility facing their stakeholders in a sustainable perspective. Sustainability and territorial values are delivered to customers and become differentiators for businesses.

Two industrial cases are analyzed below to understand how the integration of territorial resources into a company's value creation system enables the capture of intrinsic territorial values and modifies the product and its design process.

\section{Design within the territory: two industrial cases}

This part presents the analysis of two industrial practices that create sustainable values thanks to the integration of territorial resources into design process. The aim of this analysis is to highlight the potential benefits for every stakeholder and to refine the proposal.

\subsection{Approach and method}

These two companies integrated territorial resources into their business were selected to illustrate how territorial resources influence the product design and the added value for the customers, the company and its territory.

\subsubsection{Method}

The analysis is divided into 4 phases. 1 - Intangible profile of the company (what are the strategic assets?). 2- Motivation and means for territorial resource integration (why and how?). 3- Model of the decision and resources flows regarding this integration. 4- Qualitative and quantitative evaluation of the overall performance of the company, the customer and the territory.

\subsubsection{Data}

For the first case, data was collected thanks to the institutional communication of Lafarge (corporate website and sustainability report 2012). For second case, one-to-one semi-directive interviews were done in the company. The interviewees were the company's director, a workshop manager and three production operators.

\subsubsection{Model}

A decision and material flows model is presented in (Fig. 1). Passive resources (inputs) are used by active resources to achieve an outcome (output) that has added value in relation to a goal (Boyle et al., 2009). The system model of (De Rosnay, 1975) is adapted to the cases: tangible and intangible resources flows between reservoirs, and are modified by elements (activity, decision). The territorial reservoir is divided into natural, industrial, anthropic ecosystems and the social space (see Section 3.2.1). The external reservoir is excluded from the boundaries of the company's territory. An internal reservoir provides the internal resources of the company (e.g. knowledge, production means). The customer \& stakeholders reservoir is the final destination. Overall performance is evaluated for the company (e.g. knowledge), its territory (e.g. local employment) and the stakeholders (e.g. esteem value, less environmental impacts). The decision and material flow model is applyed to the Forge de Laguiole's case as an illustration (Fig. 2).

\subsubsection{Performance evaluation}

A taxonomy known as "thesaurus Bercy" (Fustec et al., 2011) has been adopted to evaluate the overall performance of the cases. This extended scorecard is an extra-financial evaluation tool based on a minimal chain of the assets that are considered necessary/sufficient for creating value within the company. It is a closed list of 10 intangible assets that are evaluated using a range of quantitative and qualitative indicators. This complements currently wellmanaged "tangible" capitals: fixed assets (i.e. plant, equipment...) and current assets (i.e. cash, bank account...) (Table 1). For the cases presented here, natural capital was hybridized with the environmental indicators from the global reporting initiative (GRI, 2006) (Table 2).

\subsection{Industrial cases}

The first case study is an industrial ecology strategy for a plurilocal company. Global strategy (IE) has to be adapted locally to the availability of tangible resources on the multiple territories of implantation. Sustainable value is created for both the company and its territories. The second case is about the benefits of integrating intangible resources (i.e. local culture and history) into the design of a product. This is a differentiating strategy initiated to preserve the originality of a product unprotected by a trademark. In this case, sustainable value is distributed to the company, its territory and the customers. 


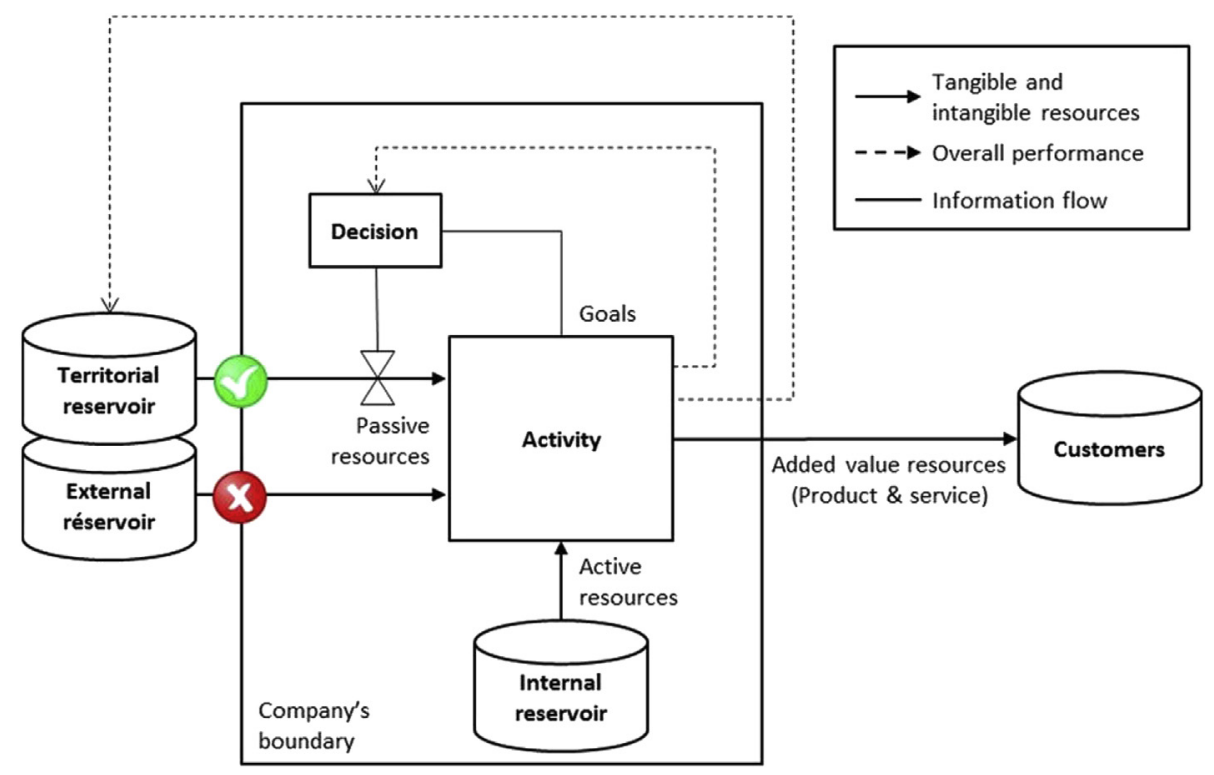

Fig. 1. Decision and material flow model.

Adapted from (Boyle et al., 2009) and (De Rosnay, 1975).

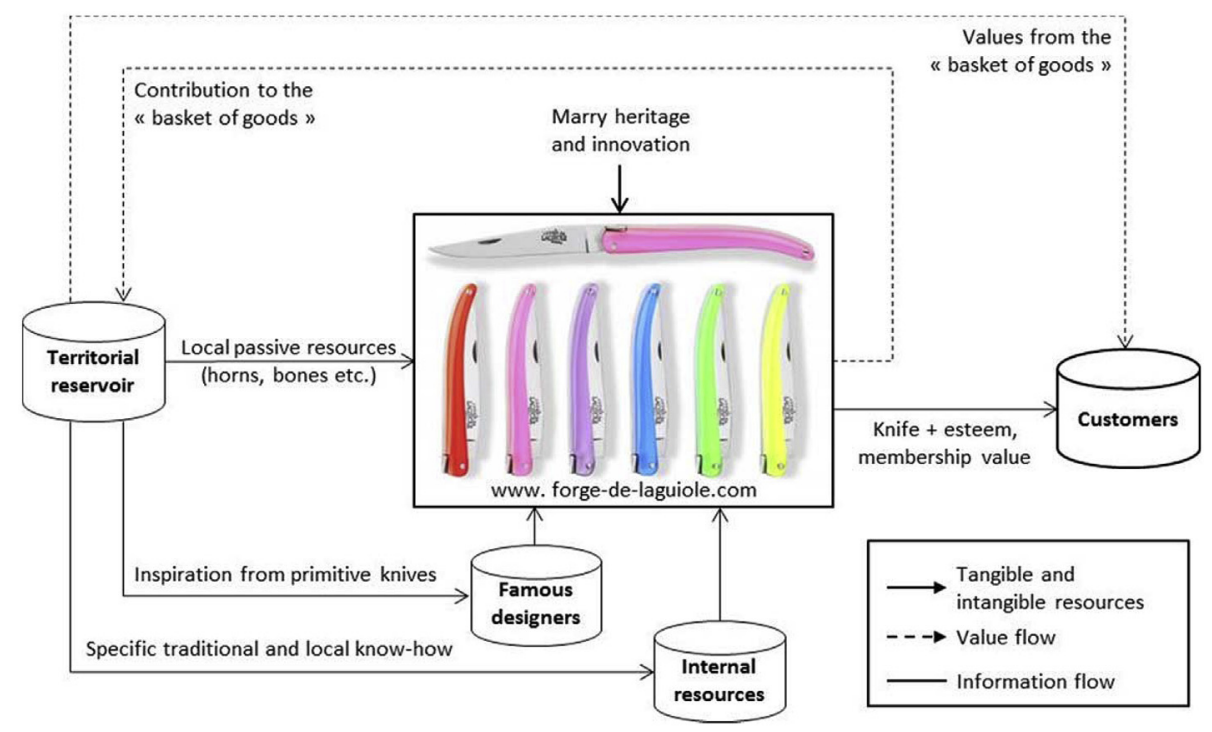

Fig. 2. Forge de Laguiole model for territorial integration.

\subsection{The cement producer}

Natural capital is a strategic asset of the cement industry. In fact, cement production consumes lot of natural resources and energy for its industrial process throughout its life cycle: extraction of clay and limestone, grinding, firing... (total energy consumption 126.84 TWh for the Lafarge group in 2012). High and fluctuating energy costs and environmental regulations ${ }^{3}$ are its main drivers for change. Fossil fuel dependence has been analyzed by senior management as a threat for the sustainability of the cement activity. So the group has adopted an industrial ecology strategy to search alternatives to fossil fuel energy sources. This strategy was deployed across the group, each production location coming up

\footnotetext{
${ }^{3}$ visit http://ec.europa.eu/resource-efficient-europe/.
}

with a tactical approach tailored to the territorial resources available to it - if available. Alternative fuels chosen are obtained from different territorial ecosystems: biomass wastes, agricultural wastes, tires, industrial waste, animal meal, urban waste, dedicated fuel crops... there are as many alternative fuels as locations. This case is not modeled here. However, (Table 3) presents three local tactics with the initial fossil resource used, the alternative local resource and an evaluation of the overall performance.

Table 1

Extended scorecard of the Thésaurus Bercy (Fustec et al., 2011).

\begin{tabular}{lll}
\hline Customer capital & Partner capital & Knowledge capital \\
\hline Societal capital & Brand capital & Shareholder capital \\
Human capital & Organizational capital & Fixed assets \\
Natural capital & Information system capital & Current assets \\
\hline
\end{tabular}


Table 2

Presentation of the companies.

\begin{tabular}{|c|c|c|c|c|c|}
\hline & Field of activity & Workforce & Size, structure & Turnover & Customers \\
\hline $\begin{array}{l}\text { Cement } \\
\text { producer }\end{array}$ & $\begin{array}{l}\text { Process industry for construction } \\
\text { materials }\end{array}$ & 65,000 & $\begin{array}{l}1570 \text { production plants } \\
\text { over the world }\end{array}$ & $€ 15816$ million & Mass market \\
\hline Knife manufacturer & Traditional knife manufacturer & 80 & Single location at Laguiole, France & $€ 4.7$ million & Niche market \\
\hline
\end{tabular}

For the three cases, alternative resources introduce complexity into the industrial process: technical complexity (e.g. preprocessing or addition of dust filters) and quality constraints (i.e. traceability). Another constraint comes from the nature and localization of the alternative resource. It has to be collected, sorted and, for seasonal production, there is a gap with industrial needs. Consequently, there is a need for a great flexibility and diversity in alternative resource supply. There are also legal issues to overcome (i.e. waste legal status). Despite all these constraints, the cement producer has deployed his global strategy (50\% of non-fossil fuel with $30 \%$ biomass in cement production for 2020) and many different tactics have been applied locally with success ( $14 \%$ of non-fossil fuel in 2012).

Regarding the available information, it can be noticed that alternative resources creates values for both the company (lower costs, environmental compliance...) and its territory (local employment, waste elimination...). It also has positive global externalities such as $\mathrm{CO}_{2}$ emission per ton of cement has decreased by $24.7 \%$ in comparison with 1990 . It has to be noted that even if the specific $\mathrm{CO}_{2}$ emission per ton decreased, $\mathrm{CO}_{2}$ gross emission rate for cement production increased slightly at 96.7Mt in 2012.

\subsection{The knife manufacturer case}

Brand capital, territorial and innovation capital are the key assets of the knife manufacturer Forge de Laguiole. The Laguiole knife was invented in the village of Laguiole in 1829 (Angeon, \& Vollet, 2008), it was a rustic knife used by farmers and cow keepers for everyday use which was handed down from generation to generation. This knife has a significant symbolic value due to its long history and is more than just an artifact of steel and horn. In fact, the knife incorporates a large number of values (e.g. heritage, culture, patrimony, quality, know-how, identity) that are promoted and reinforced by other products of the territory (e.g. local varieties of cheese and meat with a protected designation of origin), in a "basket of goods" (Roux et al., 2006; Angeon, \& Vollet, 2008), and even by the territory itself. However, customers may find Laguiole knives with a large variety of production locations, quality and cost because neither the Laguiole knife model nor the name have ever been registered as a trade mark or protected.

The strategic analysis of the current market reveals a saturation of low cost-low quality knives produced in low cost countries. The Forge de Laguiole's motivation is to preserve Laguiole's cultural heritage and "create employment in good conditions for the workforce within the territory". The differentiation strategy of Forge de Laguiole is based on two core factors: innovation and "territory and heritage". Innovation in this company is based on two pillars: well-known stylists (i.e. Philippe Starck, Sonia Rykiel...) and high level R\&D (e.g. a research program to develop a special steel grade, a patented process for wood handle preservation). The values of "territory and heritage" are expressed in the work of designers whose brief has been to update the brand's traditional models to satisfy contemporary tastes. The company's policy to contribute to its territory is reflected practically in, for example, a so-called "snail shell" tactic for the purchasing. Geographical proximity has primacy, ahead of environmental considerations and cost criteria.

For the knife design, the influence of territorial resources is omnipresent: they are the product's inspiration. Product design is outsourced to famous designers and style consultants. These resources, external to the territory and with a wealth of skills of their own, are tasked with incorporating the territory's culture and history in the product's style. The object embodies both the values associated with the territory and the modern values introduced by the designers (e.g. materials, color, form) to meet customers' expectations.

This case shows that integrating intangible values coming from the territory (i.e. tradition and know-how) can provide added value to customers and become a differentiator for the whole company. Starting from an important issue (no brand protection) the company has succeeded in finding its place in a very competitive market thanks to the use of local tangible and intangible resources. Customers benefit from this integration because of the additional values embedded in the products. The territory also gains additional value for its "basket of goods". Despite its success, Forge de Laguiole is committed to the creation of a label "made in Laguiole" to protect its specificities.

\subsection{Discussions on the industrial cases}

After pointing the limitations of these case studies, observations and results are presented.

\subsubsection{Critical analysis of results}

The first limiting factor, as far as our case studies are concerned, relates to the reliability and comprehensiveness of the data used. In fact, for the first case, data was obtained mainly from the companies' institutional communication supports and has not been

Table 3

Global performance evaluation of three different sites.

\begin{tabular}{|c|c|c|c|}
\hline & La Couronne (France) & Zunyi (China) & Bath (Canada) \\
\hline Initial resource & Fossil fuel & Coal & Coal and petroleum coke \\
\hline $\begin{array}{l}\text { Alternative } \\
\text { resource }\end{array}$ & $\begin{array}{l}\text { Industrial wastes } \\
\text { (industrial ecosystem) }\end{array}$ & $\begin{array}{l}\text { Household waste from Zunyi (800,000 hab.) } \\
\text { (anthropic ecosystem) }\end{array}$ & Fuel crop (anthropic ecosystem) \\
\hline Economic gains & Reduced fossil fuel costs & $10 \%$ improvement in fuel costs (2013) & \\
\hline Natural capital & $\begin{array}{l}\text { Reduction of fossil fuel } \\
\text { consumption }\end{array}$ & $25 \%$ of municipal waste is valorized every day & Reduction of $17 \%$ of $\mathrm{CO}_{2}$ between 2005 and 2020 \\
\hline $\begin{array}{l}\text { Relational capital } \\
\text { Societal capital }\end{array}$ & & $\begin{array}{l}\text { Long-term partnership agreement with the town } \\
40 \text { local jobs created }\end{array}$ & Partnership with WWF and local stakeholders \\
\hline
\end{tabular}


subjected to critical evaluation. Both cases may be improved by a multi-perspective and system view that consultation with other stakeholders (internal, territorial stakeholders) would have offered. Despite these limitations, data collected was sufficient to implement the conceptual framework. With respect to the methodology, conceptual framework (i.e. extended scorecard and flows model) is implemented on real cases and demonstrate its feasibility. The evaluation scorecard and the complementary framework for sustainable navigation (Zhang et al., 2013) are currently being implemented on other industrial cases. However, these are long-term experiments (strategic period of 2-3 years) and the validation of this model is not yet confirmed. Nonetheless, observations and findings regarding these particular industrial cases enable a generalized proposition in part 5 .

\subsubsection{Observation and findings}

In the case of the cement manufacturer, the system's environmental and societal performances were improved (e.g. fossil fuel consumption, employment, knowledge) for the three locations. Data confirming these assumptions have not been collected, but intangible assets such as brand capital or human capital have been positively impacted. The global cost of these projects is also unknown, even if it is reasonable to assume that it is loss-making, it may have been interesting to know the balance between financial and intangible capitals in the decision. In the case of the knife manufacturer, the territory is the company's principal differentiating factor, embedded in its cultural, historical and knowledge aspects. In this very particular case, the territory appears essential for business sustainability because it is the key factor in the value creation network of the company. The company creates value synergistically with its territory, for its clients and for its territory in a win-win-win relation. Decisions are based on the policy of territorial development before cost.

It is to be noticed that for both cases, overall strategy has initiated and supported territorial resource integration. In order to provide designers with territorial resources, the company's value constellation has to integrate previously ignored stakeholders from different ecosystems of the territory (e.g. industrials, farmers, municipal authorities...). It also has to be noticed that companies are able to initiate and develop collaboration with their territories if they understand its potential tangible and intangible plus-value. So, at the company scale it is a top-down approach (e.g. strategy to operations) but at the territorial scale it is a bottom-up initiative (e.g. company to territorial network).
In both cases, territorial resource integration into the product has consequences on the life cycle of the product and the design process itself. Consequently, territorial resource integration requires organizational innovation. Resource availability constrains the manufacturing (i.e. pre or post-processing), the development process (i.e. style, material), the sourcing (i.e. local rather than cheap), etc.

\section{Releasing the potential of territorial resources, a proposition}

With regard to the literature review and case studies, it appears that design activity is a cornerstone for integrating sustainability into companies. Territorial resources carry business and sustainable values but remain under-exploited by companies and strategic involvement and support is essential for their integration into companies. The proposition made here is to open the floodgate of territorial resources to designers thanks to a revised strategic process. Consequently, this method is first addressed to senior management but is also intended to improve the design of sustainable products.

The functional decomposition presented in (Fig. 3) is based on the classical strategic process: analysis, choice and deployment (Johnson and Scholes, 1984). The method proposes: F1- to extend the internal strategic analysis to the all of the value creation factors; F2- to support strategic decisions towards a sustainable strategy; F3- to manage the deployment from strategy to designers and the overall performance assessment of the system.

\subsection{F1- extending the internal strategic analysis to all the value creation factors}

The aim of this first function is to increase the knowledge of value constellation of the company within its territories. It concerns the knowledge of the corporate and operational governance (see Section 5.1.1), the portfolio of intangible assets of the company (see Section 5.1.2) and the value constellation extended to the territory (see Section 5.1.3).

\subsubsection{Company's governance profile}

Governance maturity grid enables on one hand the evaluation of a company's governance and on the other hand of the integration of sustainability. The company's governance profile is the qualitative evaluation of the two dimensions called means and aspiration. Each

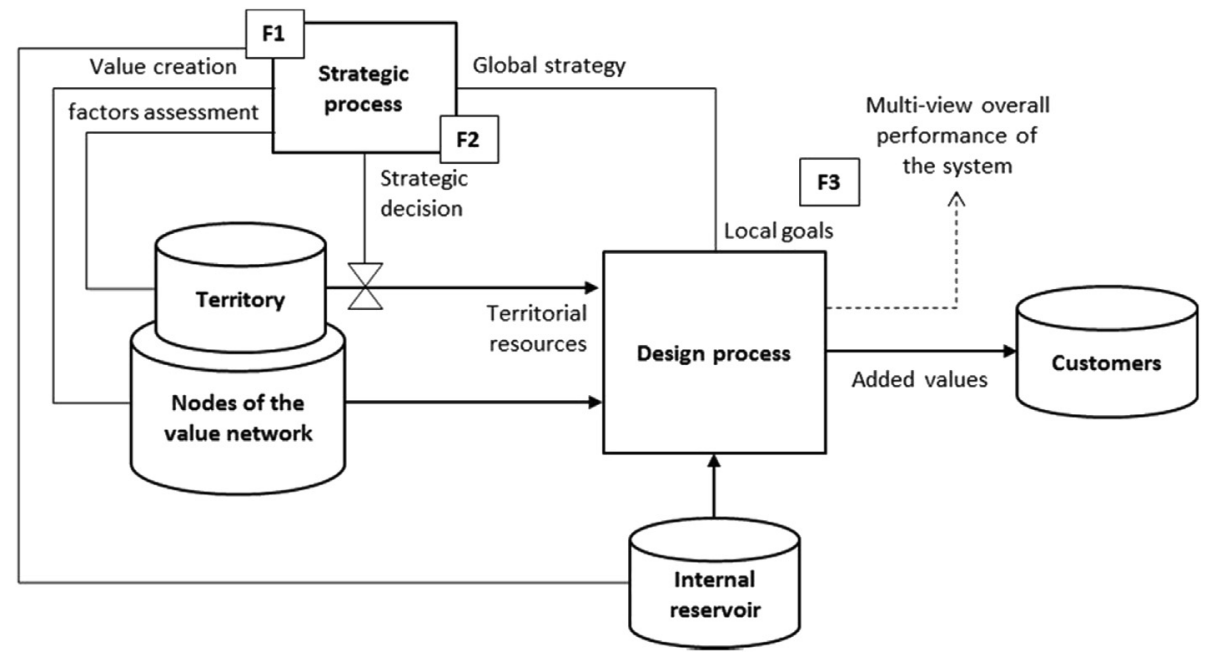

Fig. 3. Proposition to integrate territorial resources into design process. 
dimension is evaluated using 5-maturity level multiple choice questions to senior management. These maturity levels are constructed by the combination of backcasting approach (i.e. ideal definition) and existing maturity levels literature. Means are evaluated by 5 criteria for intangible integration in governance resulting from a forecasting review of economic models, literature and inquiries in companies. Aspirations are evaluated according to 4 criteria for the sustainability of the company in its ecosphere resulting from a principled backcasting approach and literature. The construction of the maturity grid is detailed in an article soon to be published (Allais et al., 2015). The company's governance profile poses questions regarding factors of value creation (both tangible and intangible): how they are integrated in strategic thinking and decisions and how they are managed (strategic and operational level). It also enables the evaluation of the integration of environmental, social and territorial dimensions into strategic thinking and how stakeholders are taken into account and empowered.

\subsubsection{Company's assets assessment}

As seen previously, intangible assets are key factors for value creation but remain underestimated. The adoption of thesaurus Bercy (see Section 4.1.4) was a first step because it enables a qualitative and quantitative evaluation of company's intangible profile in an accountability perspective. However, the anthropocentrically utilitarian outlook that dominates the structure of these tools is open to criticism. In fact, the environment is considered either as a source of risk (supply risk) or as a potential inducement to employees (attractive climate). The research described in this article makes use of these accountability and management tools. The "thesaurus Bercy" (Fustec et al., 2011) was adapted and improved to fit the research needs. That is to say a qualitative and quantitative assessment in a multiple level approach: linking global strategic indicators (10 intangible capitals) to local eco design indicators (e.g. LCA indicators). Collaboration with performance or accountability experts may refine the evaluation tool.

\subsubsection{Mapping the value constellation}

The internal value creation mapping activity aims to increase the body of knowledge relating to value-creating processes inside the business and their interactions. This mapping is a representation of the flow of tangible and intangible resources from one reservoir to another. For example, a stylist creates a trend board (final reservoir) by combining extracts (resources) from various origins (e.g. art exhibitions, famous stylists...) (initial reservoir) with a particular process. The mapping of internal processes and interactions allows the identification of a set of stakeholders linked to company's activity (e.g. suppliers, customers). In order to integrate territorial resources into company's activity, an important issue is to capture knowledge about its territories. This is not developed in this study but interesting solutions already exist for territorial data collection: territorial metabolism (i.e. material flow analysis at territorial scale), open public data ${ }^{4}$... GIS (Geographic Information System) may be used to represent these data in a multi-layer perspective: tangible resources, skills, human resources, etc. Promising research has started at the CREIDD laboratory on the connection between PLM (Product Lifecycle Management) and GIS to enable territorial data introduction into company's information systems (Vadoudi et al., 2014).

\footnotetext{
4 http://www.etalab.gouv.fr/.
}

\subsection{F2- supporting strategic decisions towards sustainable strategy}

The aim of this function is to assist senior management in choosing corporate objectives ( $\mathrm{CO}$ ) which are corporate generic strategies. $\mathrm{CO}$ are selected by senior management in the maturity grid after the governance profile evaluation so CO concerns means or ambitions. For example, environmental integration has been evaluated as "Compliance with legal requirements related to the environment that are managed occasionally as risk factors (new regulations, market demand ...)" (level 2 on 5). Senior management chooses then to work on this specific point to reach the next maturity level "Use of the environment to reduce and control costs" (level 3 on 5). The company's objective is "CO22: Mastering of the environmental costs. Target opportunities to reduce environmental costs". Maturity grids and the associated CO are used here as roadmaps to sustainability.

\subsection{F3- managing the deployment from strategy to designers and the overall performance assessment of the system}

There are 2 major issues regarding the deployment phase: first to "translate" the CO into tactical then operational goals; then to assess both local and global performance (i.e. operational, tactical and strategic performance). This third function has only been achieved for the environmental dimension in collaboration with other researchers of the Convergence project (Zhang, \& Zwolinski, 2012; Rio et al., 2013; Allais et al., 2013). The focus was on eco design methods, tools and practices. Correspondence tables enable the selection of tactical targets that are then detailed in tactical roadmaps and deployed to operations. As an illustration, the $\mathrm{CO} 22$ previously targeted is linked to "CO221: Decrease material intensity of products and services" or "CO222: Decrease energy intensity of products and services". The choice of one detailed corporate objective rather than another requires negotiation between senior management and middle management regarding their preferences and available resources. Then another correspondence table links detailed corporate objectives with tactical targets and associated tactical roadmaps detailing actions (e.g. design for recyclability). Every objective, target and action is linked with a specific performance indicator that enables their valorization (Zhang et al., 2013).

\section{Conclusions}

This article lays the foundation for the integration of territorial resources in the design process as a sustainability and differentiation strategy for industrial companies. In fact, it appears from industrial cases that integration of tangibles and intangible territorial resources into product design process adds value for the customer, the company, and its territory. This integration requires organizational innovation on the company's value creation network for product designers, suppliers, purchases and customers. The proposition is to provide designers with these alternative resources thanks to a revised strategic process. It differs from Industrial ecology in its top-down approach on the company scale (i.e. strategy to designers) which could facilitate territorial approaches driven by actors external to the company. This proposition aims to support system innovation (i.e. sustainable society, cultural change, system performance improvement) with a territorial resolution.

Even if it is dedicated to design improvement, the method is addressed to senior management as it provides decision-support tools for the strategic process. In fact, this method extends strategic analysis to the whole value constellation of the company (internal value creation network, territorial dimension and integration of intangibles) (F1); supports the selection of strategic 
objectives toward sustainability (F2) and provides tools for the implementation and valorization of this strategy (F3).

Today, the maturity grid has been tested in 2 industrial cases. The main contribution for users was to question their practice regarding strategy and governance. The selection of corporate objectives and the generation of tactical roadmaps and associated extended scorecards were also tested in these companies. This validates the feasibility of the proposition but as these roadmaps have not been implemented, effective deployment and performance assessment has not yet been tested.

The proposition to systematically include territorial resources in the design process appears promising regarding shared value creation between a company and its territory but its implementation requires profound changes for the stakeholders. Consumers have to balance cost and other values embedded in the product, the company has to refound their strategic and operational practices to create value in a sustainable perspective. All these changes must be supported by public policies that have to put the objectives back on the social sphere with a local perspective.

\section{Acknowledgments}

The authors wish to thank the French National Research Agency (ANR) for its funding of the Convergence project.

\section{References}

Allais, R., Reyes, T., Roucoules, L., 2013. Exploratory study on the inclusion of territorial resources in design process. In: International Conference on Engineering Design. ICED, Seoul, South Korea.

Allais, R., Reyes, T., Roucoules, L., 2015. Governance maturity levels: a proposition to support sustainability integration into companies. J. Clean. Prod. Spec. Issue Syst. Leadersh. Towards Sustain. submitted for publication.

Allee, V., 2000. Reconfiguring the value network. J. Bus. Strategy 21.

Angeon, V., Vollet, D., 2008. Product specificity and territorial development. The paradoxical example of the basket of goods emerging from Aubrac (Spécificité des produits et développement territorial. L'exemple paradoxal du panier de biens en émergence de l'Aubrac). Rev. d'Écon. Rég. Urbaine 4, 591-615.

Baden, D.A., Harwood, I.A., Woodward, D.G., 2009. The effect of buyer pressure on suppliers in SMEs to demonstrate CSR practices : an added incentive or counter productive? Eur. Manag. J. 27, 429-441.

Baret, P., Petit, F., 2010. Organizational learning of environmental responsibility: a structured 'journey'? (L'apprentissage organisationnel de la responsabilité environnementale: un 'cheminement' structuré?) Manag. Avenir 33, 96-115. http://dx.doi.org/10.3917/mav.033.0096.

Barnett, M.L., Darnall, N., Husted, B.W., 2014. Sustainability strategy in constrained economic times. Long. Range Plan. http://dx.doi.org/10.1016/j.lrp.2014.07.001.

Blessing, L., Chakrabarti, A., 2009. DRM, a Design Research Methodology. Springer London, ISBN 978-1-84882-586-4. http://dx.doi.org/10.1007/978-1-84882-587-

Brezet, J.C., 1997. Dynamics in ecodesign practice. UNEP Ind. Environ. 20 (1-2), $21-24$.

Brissaud, D., Frein, Y., Rocchi, V., et al., 2013. Final Report Futurprod. http://clustergospi.fr/.

Brundtland, G.H. 1987. Our Commun Future. UNO.

Bocken, N., Short, S., Rana, P., Evans, S., 2013. A literature and practice review to develop sustainable business model archetypes. J. Clean. Prod. http://dx.doi.org/ 10.1016/j.jclepro.2013.11.039.

Boyle, I.M., Duffy, A.H.B., Whitfield, R.I., Liu, S., 2009. Towards an understanding of the impact of resources on the design process. In: 17th International Conference on Engineering Design, ICED 2009, Stanford, USA.

Buclet, N., 2011a. Territory, Between Freedom and Sustainability (le territoire, entre liberté et durabilité). PUF, ISBN 978-2-13-057925-0.

Buclet, N., 2011b. Industrial and Territorial Ecology: Local Strategies for Sustainable Development? (Écologie industrielle et territoriale: stratégies locales pour un développement durable?) Villeneuve D'Ascq, Presses Universitaires du Septentrion, Collection Environnement et Société, ISBN 978-2-7574-0331-0.

Buclet, N., 2011c. The Service Economy: a Way to Rethink the Relationship Between Satisfaction of Needs and Environmental Constraints? (L'économie de fonctionnalité: un moyen de repenser la relation entre satisfaction des besoins et contraintes environnementales?). In: Les Cahier Nouveaux, vol. 78.

Chau, K.W., 2007. Integrated water quality management in Tolo Harbour, Hong Kong: a case study. J. Clean. Prod. 15, 1568-1572.

Delaplace, M., 2011. Clusters policy: the question of the relationship between business competitiveness and territorial competitiveness (La politique des pôles de compétitivité: la question de l'articulation entre compétitivité des entreprises et compétitivité des territoires). Géogr. Écon. Soc. 13, 255-271.

De Rosnay, J., 1975. Le macroscope, edition du seuil, ISBN 978-2-02-004567-4.

De Winter, A., Kals, J., 1994. A methodic approach to the environmental effects of manufacturing. In: CIRP International Seminar on Life Cycle Engineering RECY'94, Erlangen, Deutschland.

Domingo, L., Rasamoelina, f, Bouchard, C., Brissaud, D., Aoussat, A., 2013. Using environmental segmentation to perform ecodesign with users. In: International Conference on Engineering Design, ICED2013, Séoul, South Korea.

Edvinsson, L., 1997. Developing intellectual capital at Skandia. Long. Range Plan. 30 (3), 366-373.

Elkington, J., 1997. Cannibals with Forks: the Triple Bottom Line of 21st Century. New Society Publishers.

Esty, D.C., Porter, M.E., 1998. Industrial ecology and competitiveness, strategic implication for the firm. J. Ind. Ecol. 2 (1), 35-43.

Eustace, C., Bianchi, P., Cohen, L.J., Edvinsson, L., Enqvist, R., Fidler, S., Lev, B., Ramin, K.P., Vollman, T.E., Zambon, S., 2009. The Intangible Economy Impact and Policy Issues, Report of the European High Level Expert Group on the Intangible Economy. European Commission.

Fustec, A., Bejar, Y., Gounel, T., Zambon, S., Thevoux, S., 2011. French Standard for Measuring the Non-financial and Financial Value of Intangible Corporate Capital (référentiel français de mesure de la valeur extra-financière et financière du capital immatériel des entreprises). French Ministry of Economy, Finance and Industry.

Figuière, C., Rocca, M., 2008. Un développement véritablement durable : quelle compatibilité avec le capitalisme financier?. Colloque international CLERSE, la problématique du développement durable 20 ans après: nouvelles lectures théoriques, innovations méthodologiques et domaines d'extension. Lille novembre.

GRI (Global Reporting Initiative), 2006. Sustainability Reporting Guidelines V.3.0, the Global Reporting Initiative. https://www.globalreporting.org/.

Godet, M., Durance, P., Mousli, M., 2010. Creativity and Innovation in the Territories créativité et innovation dans les territoires). Report for the French Economic Analysis Council.

Habib, L., 2012. The Intangible Power to Transform Economy (La force de l'immatériel pour transformer l'économie). PUF.

Hallstedt, S.I., Thompson, a.W., Lindhal, P., 2013. key elements for implementing a strategic sustainability perspective in the product innovation process. J. Clean. Prod. 51, 277-288.

Hines, P., Holweg, M., Rich, N., 2004. Learning to evolve: a review of contemporary lean thinking. Int. J. Oper. Prod. Manag. 24 (10), 994-1011.

Holmberg, J., Robèrt, K.-H., 2000. Backcasting from non-overlapping sustainability principles, a framework for strategic planning. Int. J. Sustain. Dev. World Ecol. 7 $291-308$.

ISO14062, 2002. Environmental Management, Integrating Environmental Aspects into Product Design Development. Geneva.

ISO26000, 2010. Guidance on Social Responsibility. Geneva.

Johnson, G., Scholes, K., 1984. Exploring Corporate Strategy. Prentice-Hall, Englewood Cliffs, NJ.

Karaev, A., Lenny Koh, S.C., Szamosi, L.T., 2007. The cluster approach and SME competitiveness: a review. J. Manuf. Technol. Manag. 18-7, 818-835.

Knudsen, M.T., 2010. Environmental Assessment of Imported Organic Products. PhD thesis. http://orgprints.org/18411.

Laratte, B., Guillaume, B., Kim, J., Birregah, B., 2014. Modeling cumulative effects in life cycle assessment: the case of fertilizer in wheat production contributing to the global warming potential. Sci. Total Environ. 481, 588-595.

Lockton, D., Harrisson, D., Stantan, N., 2008. Making the user more efficient: design for sustainable behavior. Int. J. Sustain. Eng. 1 (1).

Lorino, P., Tarondeau, J.-C., 2006. From strategy to strategy processes (De la stratégie aux processus stratégiques). Rev. Française Gest. 1 (160), 307-328.

Mathieux, F., Froelich, D., Moszkowicz, P., 2008. ReSICLED: a new recoveryconscious design method for complex products based on a multicriteria assessment of the recoverability. J. Clean. Prod. 16, 277-298.

Michelin, F., Vallet, F., Reyes, T., Eynard, B., Duong, L., 2014. Integration of environmental criteria in the co-design process: case study of the client/supplie relationship in the French mechanic industry. In: Proceedings of the 13th International Design Conference. Dubrovnik, Croatia.

Millet, D., Bistagnino, L., Camous, R., Aoussa, A., 2003. Integration of new dimensions in design process, application to environmental dimension. In: International CIRP Design Seminar, Grenoble, France.

Moine, A., 2006. The territory as a complex system: an operational concept for land planning and geography (Le territoire comme un systeme complexe: un concept opératoire pour l'aménagement et la géographie). Esp. Géogr. 2 (35) $115-132$.

Normann, R., Ramirez, R., 1994. Designing Interactive Strategy: from Value Chain to Value Constellation. John Wiley \& Sons, ISBN 0-471-95086-6.

OECD, 2006. Creating Value from Intellectual Assets. OECD.

Pecqueur, B., 2001. Quality and territorial development: the case of the local basket of goods and services (Qualité et développement territorial: l'hypothèse du panier de biens et de services territorialisés). Econ. Rural, 261, 37-49.

Personnier, H., Le Dain, M.A., Calvi, R., 2013. Evaluating the failure criticality in collaborative design with suppliers. In: International Conference on Engineering Design, ICED, Seoul, South Korea.

Peteraf, M.A., 1993. The cornerstone of competitive advantage: a resource-based view. Strateg. Manag. J. 14, 179-191. 
Pialot, O., Millet, D., 2014. Why upgradability should be considered for rationalizing materials?. In: 21st CIRP Conference for Life Cycle Engineering, vol. 15, pp. 379-384.

Pigosso, D., Rozenfeld, H., McAloone, T., 2013. Ecodesign maturity model: a management framework to support ecodesign implementation into manufacturing companies. J. Clean. Prod. 59, 160-173.

Porritt, J., 2007. Capitalism, as if the World Matters. Earthscan, ISBN 978-1-84407193-7.

Porter, M.E., 2000. Location, competition, and economic development: local clusters in a global economy. Econ. Dev. Q. http://dx.doi.org/10.1177/ 089124240001400105.

Rio, M., Reyes, T., Roucoules, L., 2013. Toward proactive (eco)design process: modeling information transformations among designers activities. J. Clean. Prod. 39, 105-116.

Roux, E., Vollet, D., Pecqueur, B., 2006. Coordination of stakeholders and development of local resources. The cases of Aubrac and Baronies (Coordinations d'acteurs et valorisation des ressources territoriales. Les cas de l'Aubrac et des Baronnies). Écon. Rural. 293, 20-37.

Schiller, F., Penn, A., Basson, L., 2014. Analyzing networks in industrial ecology review of social-material network analysis. J. Clean. Prod. 76, 1-11.

Spangenberg, J.H., Fuad-Luke, A., Blincoe, K., 2010. Design for sustainability (DfS): the interface of sustainable production and consumption. J. Clean. Prod. 18, 1485-1493.
Sue, N.P., 1990. The Principles of Design. Oxford University Press.

Tan, A.R., McAloone, T.C., 2006. Understanding and developing innovative product and services: the essential elements. In: International Design Conference, Design 2006, Dubrovnik, Croatia.

Tomiyama, T., Gu, P., Jin, Y., Lutters, D., Kind, Ch, Kimura, F., 2009. Design methodologies: industrial and educational applications. CIRP Ann. Manuf. Technol. $58,543-565$.

Vadoudi, K., Allais, R., Reyes, T., Troussier, N., 2014. Sustainable product lifecycle management and territoriality: new structure for PLM. In: International Conference on Product Lifecycle Management, PLM2015, Yokohama, Japan.

Wernerfelt, B., 1984. A resource-based view of the firm. Strateg. Manag. J. 5, $171-180$.

Wheeler, D., Colbert, B., Freeman, R.E., 2003. Focusing on value: reconciling corporate social responsibility, sustainability and a stakeholder approach in a network world. J. General Manag. 28 (3).

Zhang, F., Zwolinsky, P., 2012. Toward unified environmental activities in enterprise. In: International Design Conference, Design2012, Dubrovnik, Croatia.

Zhang, F., Rio, M., Allais, R., Zwolinski, P., Reyes, T., Roucoules, L., Mercier-Laurent, E., Buclet, N., 2013. Toward a systemic navigation framework to integrate sustainable development into the company. J. Clean. Prod. 54, 199-214.

Zhao, M.-Y., Cheng, C.-T., Chau, K.W., Li, G., 2006. Multiple criteria data envelopment analysis for full ranking units associated to environment impact assessment. Int. J. Environ. Pollut. 28 (3/4), 448-464. 